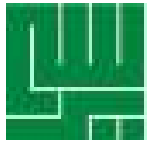

\title{
Pengaruh Kombinasi Senam Hamil dan Senam Kegel Terhadap Lama Persalinan Kala II Pada Primigravida Di Wilayah Kerja Puskesamas Karang Pule Tahun 2017
}

\section{The Effect Of Combination Pregnant Exercise And Kegel Exercise Against The Duration Of Second Stage Labor To Primigravida In The Working Area Of Karang Pule Health Center In Year 2017}

KATA KUNCI
KEYWORDS

ABSTRAK senam hamil; senam kegel; primigravida; lama persalinan kala II Pregnant exercise; Kegel exercise; Primigravida, duration of stage II labor

Senam hamil merupakan salah satu kegiatan dalam pelayanan kesehatan selama kehamilan yang memberikan out come yang lebih baik dan onset persalinan yang lebih awal dan lama persalinan yang lebih singkat dibandingkan pada ibu hamil yang tidak melakukan senam hamil. Senam kegel juga berfokus pada otot pubococsigea di area perianal yaitu dengan otot dasar panggul kuat, maka pada proses persalinan dapat mempercepat proses pendorongan bayi, sehingga dapat membantu proses persalinan dan mempercepat, serta mencegah terjadinya kala II lama yang dapat menyebabkan komplikasi pada ibu. Berdasarkan data di Wilayah Kerja Puskesmas Karang Pule diperoleh ibu yang melakukan senam hamil sebanyak 60 orang, $85 \%$ dengan persalinan normal dan 15\% mengalami komplikasi. Komplikasi persalinan berupa kejadian partus lama yaitu 3,33\%. Data tentang ibu hamil yang melakukan senam kegel dan hasil persalinan belum ada, karena belum pernah dilaksanakan.

Untuk mengetahui pengaruh kombinasi senam hamil dan senam kegel terhadap lama persalinan kala II pada primigravida.

Penelitian Quasi Eksperimen dengan pendekatan Posttest-only group design with nonequivalent groups. Populasi dalam penelitian ini adalah semua ibu hamil trimester III primigravida di Wilayah Kerja Puskesmas Karang Pule yaitu 36 orang. Teknik pengambilan sampel yang digunakan purposive sampling sesuai dengan kriteria inklusi dan eksklusi. Analisis data menggunakan analisis Univariat yaitu mean rank tiap variabel. Analisis Bivariat dalam penelitian ini menggunakan 
program SPSS (Statistical Product and Service Solution) dengan menguji hipotesis menggunakan uji Mann-Whitney.

Menunjukkan rata-rata lama persalinan kala II pada kelompok senam kombinasi (senam hamil dan senam kegel) yaitu 12,56 menit dan ratarata lama persalinan kala II pada kelompok senam yaitu 14,27 menit. Hasil uji statistik $p$ value $=0,616$ atau $p>a=0,05$.

Tidak ada pengaruh yang signifikan rata-rata lama persalinan kala II antara kelompok senam kombinasi (senam hamil dan senam kegel) dengan kelompok senam hamil pada primigravida di wilayah kerja Puskesmas Karang Pule tahun 2017.

ABSTRACT Pregnant exercise is one of the health services activity during the pregnancy gives better result of the outcome and earlier confinement and shorter the length of confinement compared to the pregnant woman who does not conduct the pregnant exercise. Kegel exercise also focuses on the pubococsigea muscleon perianal area by the floorstrong pelvic muscle so the process of confinement can accelarate the process of stemulating infant then it can helps the process of confinement and make faster also to prevent the occurrence duration of second stage which can cause complications in the mother. Based on data in Karang Pule Health Center, there were 60 mothers who performed pregnancy exercise, 85\% with normal labor and $15 \%$ experienced complications. The complication of labor which is duration parturition is $3.33 \%$. Data on pregnant mother who do kegel exercises and the results of labor do not yet exist, because it has never been implemented.

To determine the effect of a combination of pregnancy exercise and kegel exercises against the duration of second stage labor to primigravida The Quasi Experiment research by approach Posttest-only group design with nonequivalent groups. The population in this research were all primigravida third trimester pregnant mother in the Karang Pule Health Center, which were 36 people. The sampling technique used was purposive sampling according to the inclusion and exclusion criteria. Data analysis used Univariate analysis, namely mean rank of each variable. Bivariate analysis in this research used the SPSS program (Statistical Product and Service Solution) by testing the hypothesis using the Mann-Whitney test.

The research shown that the average duration of labor stage II in combination exercises group (Pregnant and Kegel exercises) was 12,56 minutes and the average duration of labor stage II in the exercise group was 14,27 minute. The statistical test result was $p$ value $=0,616$ atau $p$ $>a=0,05$.

There was no significant effect on the average duration of labor at stage II between groups of combination exercises (pregnancy exercise and kegel exercise) with pregnancy exercise groups in primigravida in the Puskesmas Karang Pule in 2017. 


\section{PENDAHULUAN}

Komplikasi maternal merupakan penyebab langsung dari kematian ibu. Setiap hari sekitar 1000 wanita atau sekitar 350.000 kematian setiap tahun meninggal karena penyebab yang dapat dicegah (WHO, 2011). Menurut data WHO tahun 2014 Angka Kematian Ibu (AKI) di dunia yaitu 289.000 jiwa, angka kematian ibu di Asia Tenggara yaitu Indonesia 214 per 100.000 kelahiran hidup.

Berdasarkan hasil SDKI 2012 menunjukkan bahwa secara nasional AKI di Indonesia meningkat drastis mencapai 359/100.000 dibandingkan pada tahun 2007 yaitu 228/100.000. Hasil ini sangat jauh dari target MDGs 2015, yaitu untuk AKI di Indonesia tahun 2015 mencapai 102/100.000 kelahiran hidup. Ada lima penyebab kematian terbesar yaitu perdarahan $30,1 \%$, HDK 26,9\%, infeksi 5,6\%, partus lama/mancet $1,8 \%$, dan abortus $1,6 \%$ dan lain-lain 34,5\%. Diperkirakan 20\% dari kehamilan atau persalinan akan mengalami komplikasi salah satunya disebabkan oleh persalinan lama atau sulit (Anik Maryuni dkk. 2011). DiIndonesia sekitar $80 \%$ kematian disebabkan oleh komplikasi yaitu perdarahan, sepsis, aborsi, pre eklamsia, serta partus lama atau mancet .

AKI untuk provinsi NTB telah mengalami sedikit peningkatan yaitu pada tahun 2012 sebanyak 100/100.000 kelahiran hidup dan pada tahun 2014 menjadi 111/100.000. (Nusa Tenggara Barat dalam angka, 2015).Adapun kejadian kematian ibu paling banyak pada waktu ibu bersalin $43 \%$, nifas 38\% dan hamil 19\%. Berdasarkan kelompok umur, kejadian kematian ibu pada usia 20-34 tahun sebanyak 58\%, usia $\geq 35$ tahun sebanyak $16 \%$ dan usia $<20$ tahun sebanyak 5\% (Dinkes NTB 2012).
Menurut Azza Ali Abd El Hamid dkk. (2012) adapun faktor-faktor yang menyebabkan persalinan lama adalah power, passenger (kelainan letak janin dan plasenta letak rendah), passage (jalan lahir yang sempit). Salah satu intervensi yang dilakukan untuk menurunkann kesakitan atau komplikasi ibu dengan peningkatan pelayanan antenatal yang mampu mendeteksi dan menangani kasus secara memadai yaitu dengan pelaksanaan kelas ibu hamil (senam hamil dan senam kegel) (Profil Kesehatan Indonesia 2014).

Senam hamil merupakan salah satu kegiatan dalam pelayanan kesehatan selama kehamilan yang memberikan outcome yang lebih baik dan onset persalinan yang lebih awal dibandingkan pada ibu hamil yang tidak melakukan senam hamil. Sehingga ibu dapat melahirkan tanpa kesulitan, serta menjaga ibu dan bayi sehat setelah melahirkan (Dinkes NTB 2012). Senam kegel ini berfokus pada otot pubococsigea di area perianal yaitu dengan otot dasar panggul kuat, maka pada proses persalinan dapat mempercepat proses pendorongan bayi, sehingga dapat membantu proses persalinan dan mempercepat. Dan mencegah terjadinya kala II lama yang dapat menyebabkan komplikasi pada ibu (Anik Maryuni dkk. 2011).

Berdasarkan laporan PWS KIA di Puskesma Karang Pule pada tahun 2015 diketahui terdapat 1.264 ibu hamil, 1.206 ibu bersalin. Jumlah ibu hamil yang melakukan senam hamil sesuai jadwal sebanyak 60 orang yang saat persaalinan sebanyak $85 \%$ dengan persalinan normal dan 15\% mengalami komplikasi.

Correspondence:

Opiani Aprianti, Diploma IV Midwifery Program of Politeknik Kesehatan Mataram

Email:opiani1@gmail.com 
Komplikasi peralinan berupa partus lama dengan kejadian 3,33\%. Data tentang ibu hamil yang melakukan senam kegel dan hasil persalinannya belum ada, karena belum pernah dilaksanakan. Senam hamil dan senam Kegel juga belum menjadi kebijakan yang wajib diterapkan di Wilayah Kerja Puskesmas Karang Pule. Kejadian partus lama lebih kecil secara bermakna yaitu 3,33\%. Akan tetapi fakta tersebut belum cukup untuk menetapkan kebijakan tentang senam hamil di Wilayah Kerja PKM Karang Pule. Karena masih sedikit data yang mengungkapkan pengaruh senam hamil terhadap lama proses persalinan.

Berdasarkan uraian di atas, maka peneliti melakukan penelitian tentang "Pengaruh Kombinasi Senam Hamil dan Senam Kegel Terhadap Lama Persalinan Kala II Pada Primigravida di Puskesmas Karang Pule Tahun 2017".

\section{CARA KERJA}

Penelitian ini menggunakan jenis penelitian Quasi Eksperimen dengan Posttest-only design with nonequivalent groups, yang bertujuan untuk mengetahui pengaruh kombinasi senam hamil dan senam kegel terhadap lama persalinan kala II pada primigravida di wilayah kerja puskesmas karang pule. Wilayah karang pule terdiri dari 5 kelurahan yaitu kelurahan karang pule, jempong baru, pagutan, pagutan timur dan pagutan barat. Jumlah penduduk di wilayayh kerja puskesmas karang pule yaitu 49.407 jiwa. Dengan cakupan K4 yaitu 1.230 bumil.

Responden Intervensi adalah ibu hamil trimester III yang melakukan senam hamil dan senam kegel. Sedangkan responden kontrol adalah ibu hamil trimester III yang melakukan senam hamil. Sumber responden intervensi dan kontrol adalah dari buku register kohor ibu hamil di polindes seluruh wilayah kerja puskesmas karang pule. Sampel yang digunakan yaitu sampel minimum sebanyak 30 sampel. Antisipasi sampel yang di drop out yakni sebesar $10 \%$ sehingga diperoleh jumlah sampel sebanyak 36 sampel. Pemilihan sampel sampel responden intervensi dan responden kontrol menggunakan teknik purposive sampling.

Variabel terikat dalam penelitian ini adalah lama persalinan kala II pada primigravida dan variabel bebas yaitu senam kombinasi (senam hamil dan senam kegel) dan senam hamil.

Metode yang digunakan dalam pengumpulan data yaitu pengumpulan data tentang karakteristik ibu (umur, tingkat pendidikan, pekerjaan). Informasi terkait dalam penelitian ini dikumpulkan melalui wawancara masing-masing responden (ibu yang tercatat dalam register ibu hamil) dengan cara memberikan informed consent. Dan menggunakan media leaflet, video dan lembar observasi senam dalam pelaksanaan. Frekuensi senam kombinasi (senam hamil dan senam kegel) yang dilakukan dengan frekuensi senam hamil 3 kali dalam satu minggu selama 3 minggu berturut dan senam kegel dilakukan minimal satu kali dalam sehari dan senam hamil saja dilakukan dengan frekuensi 3 kali dalam seminggu selama 3 minggu berturut. Data lama persalinan kala II diambil dari rekam medik.

Data dianalisis secara bivariat untuk mendapatkan rerata lama persalinan kala II setiap responden intervensi maupun kontrol dengan menggunakan uji Mann-Whitney. 
HASIL

Tabel 1. Distribusi Responden pada

Kelompok Intervensi dan Kelompok Kontrol Berdasarkan Umur Di Wilayah Kerja Puskesmas Karang Pule Tahun 2017

\begin{tabular}{lll}
\hline $\begin{array}{l}\text { Umur } \\
\text { (Tahun) }\end{array}$ & Jumlah & $\begin{array}{l}\text { Persentase } \\
(\%)\end{array}$ \\
\hline$<20$ & 6 & 19,35 \\
$20-35$ & 25 & 80,65 \\
$>35$ & 0 & 0 \\
Total & 31 & 100 \\
\hline
\end{tabular}

Berdasarkan Tabel 1. Distribusi responden terbanyak berdasarkan umur responden adalah responden yang berada pada kelompok umur yaitu umur 20-35 tahun sebanyak 25 orang $(80,65 \%)$, dan terendah pada kelompok umur $<20$ tahun sebanyak 6 orang $(19,35 \%)$.

Tabel 2. Distribusi Responden Berdasarkan

Tingkat Pendidikan Di Wilayah Kerja

Puskesmas karang Pule Tahun 2017

\begin{tabular}{lll}
\hline $\begin{array}{l}\text { Tingkat } \\
\text { Pendidikan }\end{array}$ & Jumlah & $\begin{array}{l}\text { Presentase } \\
(\%)\end{array}$ \\
\hline $\begin{array}{l}\text { Pendidikan } \\
\text { Dasar }\end{array}$ & 20 & 63,52 \\
Menengah & 9 & 28,03 \\
Tinggi & 2 & 6,45 \\
Total & 31 & 100 \\
\hline
\end{tabular}

Berdasarkan Tabel 2. didapat responden terbanyak dari kelompok pendidikan dasar yaitu sebanyak 20 orang $(63,52 \%)$, dan terendah dari kelompok pendidikan tinggi sebanyak 2 orang $(6,45 \%)$.
Tabel 3. Distribusi Respnden Berdasarkan Pekerjaan Di Wilayah Kerja Puskesmas karang Pule Tahun 2017

\begin{tabular}{lcc}
\hline Pekerjaan & Jumlah & $\begin{array}{l}\text { Persentase } \\
(\%)\end{array}$ \\
\hline IRT & 27 & 87,1 \\
Pedagang & 2 & 6,45 \\
Lain-lain & 2 & 6,45 \\
Total & 31 & 100 \\
\hline
\end{tabular}

Berdasarkan Tabel 3. didapat responden terbanyak dari ibu rumah tangga (IRT) sebanyak 27 orang $(87,1 \%)$, pedagang sebanyak 2 orang $(6,45 \%)$, lain-lain sebanyak 2 orang $(6,45)$.

Tabel 4. Distribusi Rata-Rata Lama Persalinan Kala II Pada Kelompok Senam Kombinasi (Senam Hamil Dan Senam Kegel) dan Kelompok Senam Hamil Di Wilayah Kerja Puskesmas Karang Pule Tahun 2017

\begin{tabular}{llccccc}
\hline Variabel & Perlakuan & n & max & Min & Mean & $\begin{array}{c}\text { Std. } \\
\text { Deviation }\end{array}$ \\
\hline $\begin{array}{l}\text { Lama } \\
\begin{array}{l}\text { Persalinan } \\
\text { Kala II } \\
\text { (menit) }\end{array}\end{array}$ & Kenam Kombinasi & 16 & 5 & 35 & 12,56 & 9,018 \\
& Senam Hamil & 15 & 5 & 40 & 14.27 & 10.194 \\
\hline
\end{tabular}

Berdasarkan Tabel 4. diperoleh rata-rata lama persalinan kala II pada kelompok senam kombinasi (senam hamil dan senam kegel) yaitu 12.56 menit, standar devisiasi 9,018 menit, waktu persalinan kala II paling cepat yaitu 5 menit dan paling lama 35 menit. Sedangkan rata-rata lama persalinan kala II pada kelompok senam hamil yaitu 14.27 menit, standar devisiasi 10,194 menit, waktu persalinan kala II paling cepat yaitu 5 menit dan paling lama 40 menit. 
Tabel 5. Pengaruh Kombinasi Senam Hamil Dan Senam Kegel Terhadap Lama Persalinan Kala II Pada Primigravida Di Wilayah Kerja Puskesmas Karang Pule Tahun 2017

\begin{tabular}{lccc}
\hline $\begin{array}{l}\text { Rata-Rata } \\
\text { Lama }\end{array}$ & & $\begin{array}{l}\text { Mean } \\
\text { rank }\end{array}$ & $\begin{array}{l}\text { Asymp.sig } \\
\text {.(2-tailed) }\end{array}$ \\
$\begin{array}{l}\text { Persalinan } \\
\text { Kala II }\end{array}$ & $\mathrm{n}$ & & \\
\hline $\begin{array}{l}\text { Senam } \\
\text { Kombinasi } \\
\text { Senam }\end{array}$ & 16 & 15,22 & \\
$\begin{array}{l}\text { Hamil \& } \\
\text { Senam Kegel) }\end{array}$ & & & 0,616 \\
& & & \\
Senam Hamil & 15 & 16,82 & \\
\hline
\end{tabular}

Dari Tabel 5. Disajikan hasil perbandingan rerata lama persalinan kala II pada kelompok intervensi dan kelompok kontrol. Terlihat bahwa mean rank lama persalinan kala II pada kelompok intervensi sebesar 15,22 dan pada kelompok kontrol sebesar 16,82 dengan Asymp.sig (2-tailed) sebesar 0,616 . Ini menunjukkan nilai $p$ value $=0,616$ atau $\mathrm{p}>\mathrm{a}=0,05$, berarti terlihat tidak ada pengaruh yang signifikan rata-rata lama persalinan kala II antara kelompok senam kombinasi (senam hamil dan senam kegel) dengan kelompok senam hamil pada primigravida di wilayah kerja Puskesmas Karang Pule tahun 2017.

\section{PEMBAHASAN}

Berdasarkan hasil penelitian ini diperoleh rata-rata lama persalinan kala II pada kelompok intervensi lebih cepat yaitu 15,22 dibandingkan kelompok kontrol yaitu sebesar 16,82, akan tetapi Berdasarkan uji statistik menggunakan uji mann-Whitney diperoleh nilai $p$ value $=0,616$ atau $p>a=0,05$, maka $\mathrm{H} 0$ diterima yaitu berarti terlihat tidak ada pengaruh yang signifikan rata-rata lama persalinan kala II antara kelompok senam kombinasi (senam hamil dan senam kegel) dengan kelompok senam hamil pada primigravida diwilayah kerja Puskesmas Karang Pule tahun 2017.

Peneliian ini selaras dengan penelitian sebelumnya mengenai latihan kegel dilakukan oleh Rooplekha Chauhan dkk. (2016) yaitu Korelasi antara durasi latihan (dalam minggu) dan durasi fase laten dan fase aktif dari tahap awal persalinan, menujukkan pada kelompok studi, durasi rata-rata fase laten $(7,56( \pm 2,02)$ jam $)$ dan fase aktif tahap pertama persalinan $(3,26( \pm$ 1,06) jam) secara signifikan lebih rendah dibandingkan dengan kelompok kontrol, 89,3\% ( $\mathrm{n}=134)$ melahirkan melalui vagina dan 10,7\% ( $n=16)$ (Profil Kesehatan Indonesia 2014). Ini selaras dengan penelitian Azza Ali Abd El Hamid, dkk. 2012 mengenai total durasi persalinan, ibu hamil dalam kelompok penelitian memiliki durasi persalinan yang lebih singkat daripada pada kelompok kontrol, secara statistik ditemukan perbedaan yang signifikan antara kedua kelompok $(\mathrm{P}<0,001)$.

Hal ini menunjukkan latihan senam kegel pada proses persalinan dapat mempercepat proses pendorongan bayi, sehingga dapat membantu proses persalinan dan mempercepat (Anik Maryuni dkk. 2011). Penelitian telah menunjukkan bahwa melakukan senam kegel secara teratur selama dan setelah kehamilan dapat mengurangi kemungkinan komplikasi.

Beberapa penelitian mengenai manfaat senam hamil terhadap proses persalinan telah dilakukan tetapi hanya sedikit yang menjelaskan pengaruh 
senam hamil terhadap lama persalinan kala II. Salah satu penelitian Leticia dkk. (2011) juga mempelajari efek latihan otot panggul dasar melalui uji coba terkontrol secara acak, yang menunjukkan bahwa, Tidak ada perbedaan antara kelompok pelatihan dan kelompok kontrol terkait dengan durasi kala kedua. Penelitian yang melihat pengaruh senam hamil terhadap lama persalinan kala II juga, telah dilakukan oleh Agur W et al., (2008), menunjukkan senam hamil pada primigravida kehamilan 20-36 minggu dapat mengurangi insiden partus lama namun tidak memperpendek durasi kala II antara kelompok senam hamil dan kontrol.

Adapun hasil penelitian oleh Azizah (2011), menunjukkan bahwa ibu yang teratur senam hamil terdapat $92 \%$ mengalami lama proses persalinan normal dan $8 \%$ tidak normal. Sedangkan ibu yang tidak teratur mengikuti senam hamil terdapat $43 \%$ mengalami proses persalinan normal dan 57\% tidak normal. Penelitian ini selaras dengan penelitian Hendarmin dkk. (2010), menunjukkan bahwa ada pengaruh yang bermakna antara senam hamil terhadap proses persalinan dengan uji statistik ( $\mathrm{p}$ value $=0,014$ ). Penelitian lain juga dilakukan oleh Ignatio Rika Haryono dkk. (2010) di RS Sint Carolus yang, menunjukkan durasi partus kala II pada primigravida yang melakukan senam hamil lebih pendek dibandingkan dengan yang tidak melakukan senam hamil. Adapun penelitian yang dilakukan oleh Siti Farida dkk. (2015) juga menyatakan bahwa rata-rata proses persalinan (kala I \& kala II) berbeda antara ibu yang tidak melakukan senam hamil. Ibu yang melakukan senam kala I berlansung selama 4 jam \& kala II 1 jam, sedangkan yang tidak senam hamil kala I berlangsung 11 jam \& kala II berlangsung 2 jam.

Dari berbagaai penelitian terdahulu, terdapat perbedaan dari penelitian ini, yaitu kemungkinan disebabkan oleh waktu penelitian lebih lama dan jumlah responden lebih banyak, seperti diketahui bahwa semakin besar sampel yang dianalisis akan semakin besar menghasilkan kemungkinan penelitian menjadi lebih bermakna. Seperti penelitian yang dilakukan oleh Izzatul yazidah dkk. (2010) di RSKIA Sadewa Yogyakarta, masa penelitian 6 bulan menunjukkan senam hamil dapat mempersingkat lama persalinan kala II pada wanita primigravida. Hal ini ditunjukkan bahwa wanita primigravida yang melakukan senam hamil akan mengalami lama persalinan kala II $<1$ jam.

Penelitian lain juga dilakukan oleh Tika puspita, dkk (2015) di RS Rahmi Kota yogyakarta, menunjukkan hasil penelitian ada hubungan frekuensi senam hamil dengan lama persalinan kala II di RB Rahmi kota yogyakarta dengan hasil analisis yaitu $X^{2}$ hitung $>X^{2}$ tabel $(4,848>3,841)$ atau $p$ value $<0,05(0,028<0,05)$ yang berarti ada hubungan frekuensi senam hamil dengan lama persalinan kala II.

Penelitian ini memiliki kekurangan yang mungkin dapat menimbulkan bias karena data yang diperoleh peneliti sepenuhnya melihat rekam medis. Penanganan pasien oleh bidan yang berbeda dapat menyebabkan perbedaan dalam menentukan dimulainya kala II sehingga dapat menimbulkan perbedaan lama persalinan kala II. Disamping itu tidak diketahui aktivitas olahraga lain yang dilakukan sebelum 
dan sesudah kehamilan yang mempengaruhi kekuatan otot-otot dasar panggul sehingga mempengaruhi kekuatan otot-otot dasar panggul sehingga mempengaruhi lama persalinan kala II dan tidak diketahuinya keefektifan responden melakukan senam secara mandiri dirumah, sehingga mempengaruhi lama persalinan kala II.

Dari berbagai penelitian yang dipaparkan pada penelitian ini, melakukan senam kombinasi (senam kegel dan senam hamil) dan senam hamil saja pada dasarnya sama. Dilihat dari rata-rata lama persalinan kala II terbukti memperpendek lama persalinan kala II pada kelompok intervensi maupun kontrol pada umumnya. Akan tetapi pada penelitian ini pengaruh rata-rata lama persalinan kala II tidak terlalu bermakna pada kedua kelompok. Hasil uji statistik yakni didapatkan hasil perhitungan nilai $\mathrm{p}$ value $=0,616$ atau $\mathrm{p}>\mathrm{a}=0,05$, maka H0 diterima, berarti tidak ada pengaruh yang signifikan rata-rata lama persalinan kala II antara kelompok kombinasi (senam hamil dan senam kegel) dan senam hamil. Sehingga perlu ada kelanjutan dalam penelitian ini agar lebih mengetahui ada tidak pengaruh dari melakukan senam hamil dan senam kegel tersebut dengan frekuensi yang lebih serta waktu dan biaya yang lebih juga.

\section{SIMPULAN}

Berdasarkan hasil penelitian yang dilakukan, diperoleh rata-rata lama persalinan kala II pada kelompok intervensi lebih cepat yaitu 15,22 dibandingkan kelompok kontrol yaitu sebesar 16,82, akan tetapi berdasarkan uji statistik menunjukkan nilai $p$ value $=0,616$ atau $p>a=0,05$, berarti terlihat tidak ada pengaruh yang signifikan rata-rata lama persalinan kala II antara kelompok senam kombinasi (senam hamil dan senam kegel) dengan kelompok senam hamil pada primigravida diwilayah kerja Puskesmas Karang Pule tahun 2017.

\section{Ucapan terimakasih}

Ucapan terimakasih penulis sampaikan kepada ibu-ibu yang menjadi responden penelitian ini serta semua pihak yang telah membantu sehingga penelitian ini bisa terlaksana sesuai dengan yang direncanakan.

\section{KEPUSTAKAAN}

Agur W, Steggles P, Waterfied M, Freeman $R$ 2008. Does antenatal pelvic floor muscle training affect the outcome of labor? A randomized controlled trial. Int Urogynecol J Pelvic Floor Dysfunct. 2008;19(1):85-8.

Anik Maryuni, Yetty Sukaryati 2011. Senam Hamil, Senam Nifas Dan Terapi Musik. CV Trans Info Media. Jakarta.

Azizah Y 2011. Hubungan Keteraturansenam Hamil Dengan Lamanya Proses Persalinan. Surabaya : Pustaka Pelajar.

Azza Ali Abd El Hamid, Hanan Fahmy Azzam, Gehan Moustafa Ismail, Hasan Mostofa Gaafar 2012. Effect o Structured Antenatal Kegel exercise Protocol on Labor Progres among Women attending Antenatal Clinics. Lecturer of Obstetrics \& Gynecology, Faculty of Medicine, Cairo University. Egyptian nursing journal, Vol (3), No (2), ISSN, 2090-6021.

DinKes NTB 2012. Profil Kesehatan Nusa Tenggara Barat. NTB

Gyuton and Hall 2007. Fisiologi Kedokteran. Edisi ke 11. EGC. Jakarta. Indonesia.

Hendramin Aulia, Siti Hindun 2010. Pengaruh Senam Hamil Terhadap Proses Persalinan Normal Di Klinik YK 
Mandira Palembang. Jurnal Kedokteran \& Kesehatan. Fakultas Kedokteran Universitas Sriwijaya. Palembang. JKK, Th.42 No.1 Januari 2010.

Ida 2012. Senam Hamil. Didapat dari http://www.mediabangsa.com/home /112-kehamilan/572-senam hamil.pdf. tanggal akses 30 November 2013.

Ignatio Rika haryono, dkk. 2010. Perbedaan Durasi Partus Kala II Antara Primigravida Yang Melakukan Dan Yang Tidak Melakukan Senam Hamil. Damianus Journal Of Medicine : Vol.9 No.1 Februari 2010: hlm 1-5.

Izzatul yazidah, Sribin hasibuan 2010. Hubungan senam hamil terhadap lama persalinan kala II pada wanita primigravida di RSKIA Sadewa Yogyakarta. Yogyakarta. JKKI, VOL.2 NO.6, JULI 2010.

Leticia A, Dias R, Driusso P, Daniella L, Aita C, Silvana M, Quintana C, Kari B, Cristine H, and Ferreira J 2011. Effect of pelvic floor muscle training on labour and newborn outcomes a randomized controlled trial. 15(6):487-93.
Profil Kesehatan Indonesia. 2014. Kasus Angka Kematian Ibu di NTB. NTB.

Rooplekha chauhan, bharti sahu, neetu singh, ritika malviya, priyadarshani tiwari 2016. Enhancing norml labour by adopting antenatal physiotherapy : a prospective study. International Journal of Reproduction, Contraception, Obstetrics and Gynecology Chauhan $\mathrm{R}$ et al. Int J Reprod Contracept Obstet Gynecol. 2016 Aug;5(8):2672-2676.

Siti Farida, Sunarti 2015. Senam Hamil Sebagai Upaya Mempelancar Proses persalinan Di Rumah Sakit Kasih Ibu Surakarta. Skripsi Akademi Kebidanan Citra Medika, Surakarta.

Tika puspita, Eko mindarsih CH.M, Widhi hartini 2015. Hubungan frekuensi senam hamil dengan lama persalinan kala II di RS Rahmi Kota yogyakarta. Yogyakarta.

WHO 2014. Mortality and Demographic Data 2014. Ministry Of Health, World Health. 